\title{
Exploring the Sport's Potential of Primitive Tribes
}

\author{
Sukendro $^{1}$, Fredrik Alfrets Makadada ${ }^{2}$ \\ 1 Universitas Negeri Jambi, Indonesia \\ 2Universitas Negeri Manado, Indonesia \\ Email: sukendrodasar@yahoo.co.id
}

\begin{abstract}
The study aims to exploring the sport's potential of primitive tribes. The habitation of primitive tribe is far into the forest which is difficult to reach by vehicles and must walk approximately $25 \mathrm{~km}$ from the nearest village or hamlet, this illustrates the endurance of their lungs very well. The result shows that coordination and agility are very good, because they have strength and agility in terms of climbing which in itself will have good arm strength and leg grip. Besides that they are proficient in hunting because hunting is the most important livelihood, they have the knowledge to succeed: the forest situation, natural signs, animal signs and how to catch them, because since childhood this generation has been trained to live deftly in the forest, of course has incredible speed and reaction and strength in getting hunted animals.

Keywords: sport; potential; primitive tribes
\end{abstract}

\section{Introduction}

Indonesia is an archipelagic country inhabited by many ethnic groups with a variety of cultures. In some areas there are still many tribal groups that live isolated from the influence of the outside world. The Ministry of Social Affairs of the Republic of Indonesia labeled the isolated community groups as isolated communities. No exception in Jambi Province which is still inhabited by Kubu or primitive tribes.

The Ministry of Social Affairs of the Republic of Indonesia labeled the isolated community groups as isolated communities. Through the presidential decree of the Republic of Indonesia Number 111 of 1999 concerning the Development of Social Welfare of Remote Indigenous Communities, since 13 September 1999 the term isolated community has been replaced by Remote Indigenous Communities. Article 1 of the presidential decree No. 111 of 1999, what is meant by Remote Indigenous Communities is social and cultural groups that are local and scattered and have little or no involvement in social, economic or political networks and services.

Primitive tribes is one of the Remote Indigenous Communities in Jambi Province that has specific problems, if viewed from their life patterns and livelihoods, this is due to the strong bound to customs. Living in groups with clothes only partially covers the body, in other words they are very dependent on forest/natural products and animal hunted. The name of Kubu has many meanings, according to Indonesia Dictionary, Kubu has five meanings namely:

1. Fences made by wood and given a layer of soil and so on to withstand attacks.

2. Defensive place reinforced with fences

3. Place that has a strong fence (to catch large animals such as elephants)

4. Place of defense.

5. A group of supporters. 
The Kubu definition itself in Jambi Malay means a hiding place or "Stupid" this name comes from the presence of villages called "Kubu Kandang" and "Pengabuan" on the banks of the Batanghari River. Possibly these villages were their initial settlement.

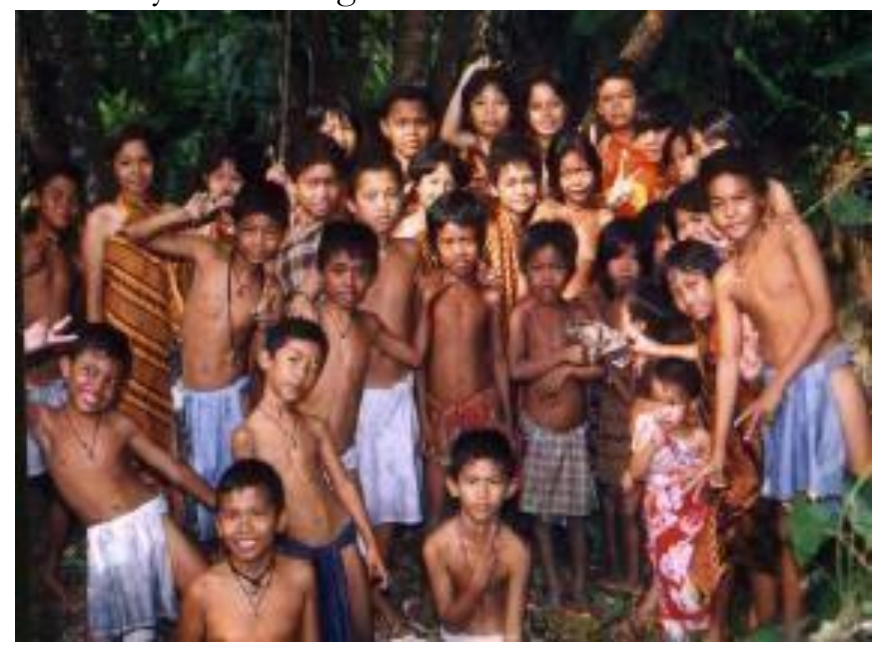

Source: Wahyudikuncoro

Figure 1. Some of primitive tribes are already associated with the surrounding community

The understanding Kubu which means stupid, is very unpleasant to hear because there is a condescending impression, therefore they are reluctant to be called Kubu people, they prefer to be called themselves as "Children In", Orang Rimbo or "Orang Kelam" while the surrounding community are called "Orang Terang". If we observe from the life and physical activities of the primitive tribe, they tend to have athletic sports talent, this is illustrated from the description above. If related to the theory conveyed by Bompa, so the age under study is very closely related to what we expect.

From the age of 8 to 10 years, hands can be used freely, easily and precisely. Fine motor coordination is developed, where children are able to write well. The font size becomes smaller and neater. At the age of 10 to 12 years, children begin to display manipulative skills resembling adult abilities. A form of development of the body, the individual's body which is followed by his activities towards something and his environment. Individuals in their life span from the first years to the following years reach the puberty period experiencing rapid growth and change.

\section{Review of Literature}

Many primitive tribes use rice as their daily staple food. They get the rice from buying in the hamlets or the community who come to their location. Actually, their staple food in the past is all kinds of tubers that grow in the forest, such as taro, cassava, sweet potatoes, tuber silung and animal hunted such as wild boar, deer, mouse deer and others.

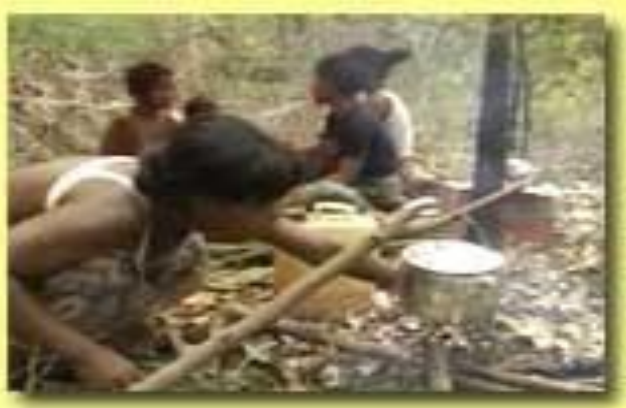

Figure 2. How the way they cook is very simple 
Humans are part of nature, not separate from it, and without nature human cannot achieve health and continue the human existence. Like other animals, humans must consume foods that are in accordance with the specifications of their own species and the environment in which they live. The basic principle of human life is to eat plants and animals that live naturally in their area. For humans who are accustomed to foods consisting of whole grains, vegetables, fruits, and fish, meat which is full of chemical spices, milk, and many processed foods and excessive enzyme-rich quantities cannot be digested.

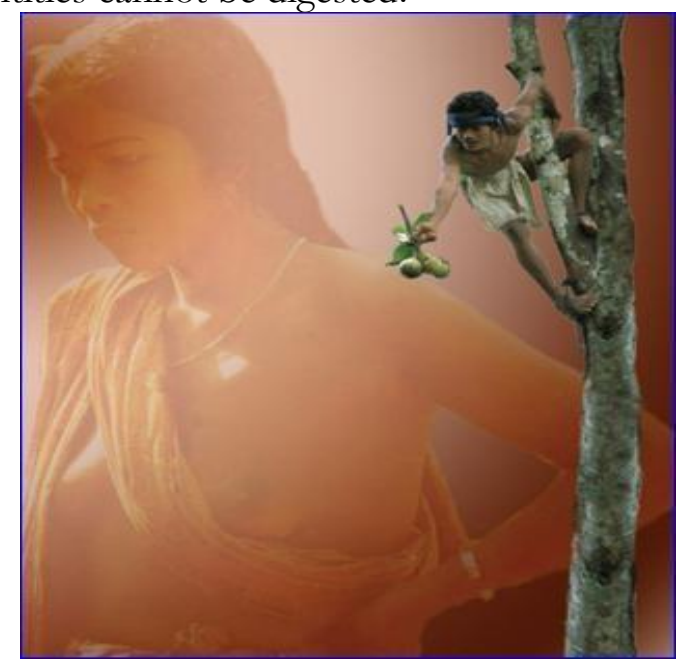

Figure 3. Primitive tribe in relying on food in forest

They are generally not clothed, but they use a cloth loincloth to cover their genitals. In the past, they used the loincloth made of applied bark or serdang, but because the loincloth made of bark often caused pain due to woodlice entering the skin, so they left it and switched with the cloth they bought in the market through the general public.

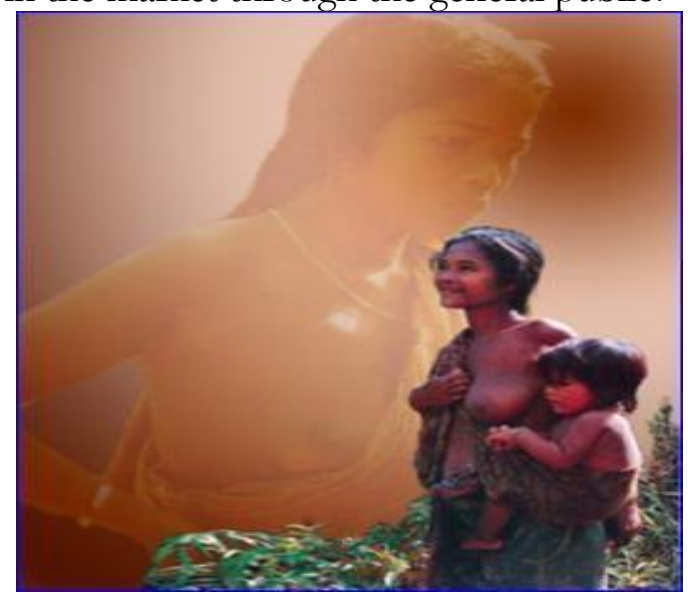

Figure 4 . The clothes of primitive tribe is very simple

The fabric type and color are free and the way to wear it is adjusted by themselves. For women it is very difficult to see because there are restrictions, even if she sees outsiders always avoiding / running. But according to Tumenggung that the primitive tribe women whose women only dressed covered the waist while their breasts were left open. In terms of day-to-day appearance, they wear loincloths for men made of sarong, but when they come out of the jungle there are those who already wear ordinary clothes but underneath still wear loincloths while the women wear sarong that is attached to the chest.

The definition of athletics is a sport that consists of a combination of several types of physical sports, such as running, throwing, jumping, and walking. Another opinion says athletics 
are a type of physical sport that uses track and field; like walking, running, high jumping and javelin throwing. In other words, athletics refer to any type of sport, exercise, or game that uses physical human beings.

Etymologically, the term "Athletics" comes from the Greek word Athlon, which means race or contest. Referring to the origin of the word athletic, the meaning of athletics can be defined as a race of certain branches of sport (walking, running, jumping, and throwing). In order to better understand what athletics is, we can refer to the opinions of the following experts:

According to Mochammad Djumidar A. Widya, athletics is an element of physical education and health. Athletics is a component of overall education that prioritizes physical activities as well as the fostering of healthy living and physical, mental, social, and emotional development in harmony, harmony, and balance. According to Eri Periatama, the definition of athletics is a sport that most of its activities are carried out on track and field sports. According to Muhajir, the meaning of athletics is a type of sport that grows and develops together with natural human activities, such as walking, running, jumping, and throwing.

\section{Discussion}

The primitive tribes has physical skills, which are so high compared to bright people (ordinary people), and has a high level of fitness. This is almost the same if we do daily sports activities. As has been said by William.F, that sport is a form of play activity which is organized in such a way with a set of rules and contested using benchmarks of the physical skills of the offender.

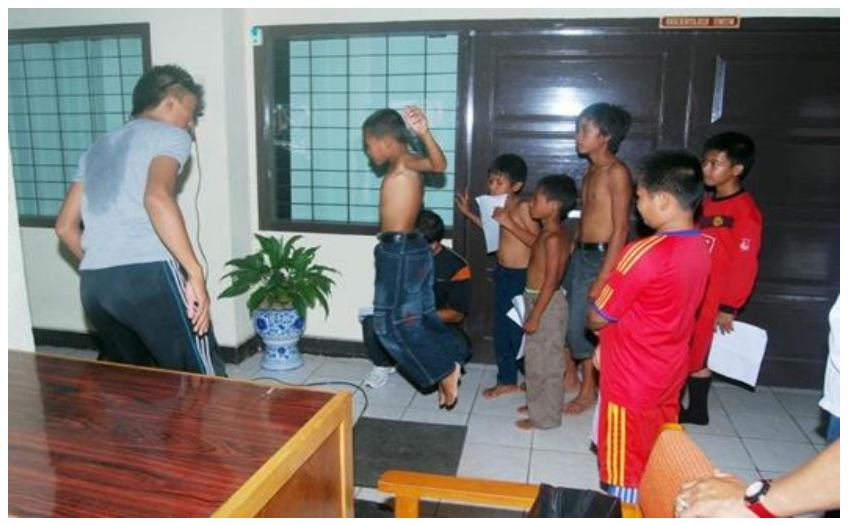

Source: Sukendro 2011

Figure 5. Verical Jump test of primitive tribes

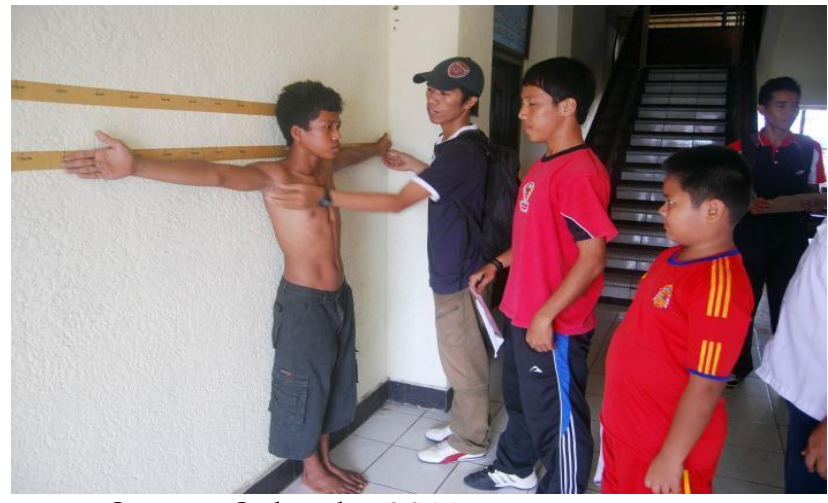

Source: Sukendro 2011

Figure 6. Arm length test of primitive tribe 
As we all know that sport itself has different goals and desires than doing physical human activities. One of them is to excel. As expressed by A. Ateng. The goal of sports achievement is to show the highest motor behavior to be able to win in a match/race, the contents are targets to be mastered, the orientation is only on athletes who are able to achieve the goals and objectives set, their nature is to find talented athletes for achievement with activities that are tends to be adjusted to match situation.

National sports systems must pay attention to factors of values and climatic conditions, culture and attention to the sport itself, especially for young athletes. From the above description it can be stated that the application of the sports coaching system cannot be compared, it must look at the potential, talents and characteristics of the community in order to produce high sports achievements. We have to find someone's talent and we explore his abilities both from the physical and psychological aspects.

According to Singgih, sport talent is a process that is owned by someone who can excel in sports. Therefore talent scouting aims to identify potential athletes who have the potential to be compatible with the athlete's factors and the demands of the sport that athletes choose. While Harre believes the purpose of identifying talent is to predict a high degree of the likelihood of whether an athlete will be able and successfully complete an exercise program in a chosen sport, so that he can measure with certainty, do the next stage of training.

Talent is an individual's unique characteristic that makes it able (unable) to do an activity and task easily or difficult and is successful or never able. The natural abilities that humans bring will bring better life things to do things like: sports, music, and organization. Bompa said that the method of identifying talent can be done in two ways, namely:

1. Ways of natural selection

2. Scientific selection

Natural selection is a method that is done with a normal approach and is a way of developing nature in a particular sport branch or number. Whereas scientific selection is a method used to select potential athletes who have the potential to be fostered by scientific selection, the physical qualities of talented athletes can be detected.

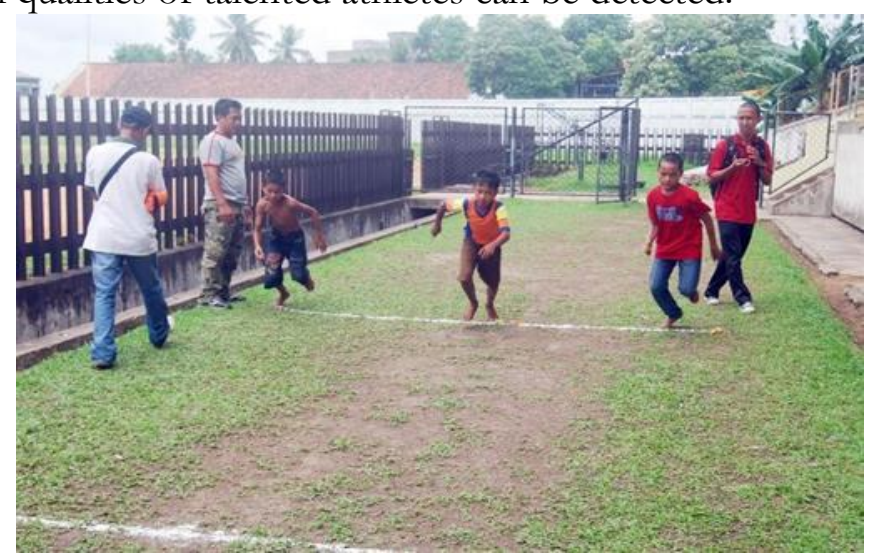

Source: Sukendro 2011

Figure 6. Shuttle run test of primitive tribe

In identifying talent can be done by looking at the conditions of prospective athletes that are tailored to the branch of sport to be selected, for example selecting candidates for highachieving athletes for basketball. While the sophisticated method is carried out oriented in sports 
science and technology as outlined in a comprehensive test kit or battery test to see the potential possessed by the prospective athlete.

This is related to what researchers do in identifying athlete talent by using tests (Sport Search). The gradual implementation of the coaching system can be done through basic and tiered training done through sports clubs in schools and other sports clubs. The search for the interests and talents of potential athletes must be carried out by identifying interests and talents based on sports science and technology through a comprehensive set of test batteries.

In essence, every dexterity exhibited in sports such as athletics, in running, throwing and jumping numbers, is part of basic human movements or actions, occurring since humans existed. Once upon a time people used their abilities or dexterity for hunting purposes and to avoid attacks by wild animals. But with the development of weapons, abilities/kills or dexterity channeled towards filling leisure time in the form of leisure sports.

The Greeks is the first big nation to organize and manage an athletic race in their country by organizing what we know about the ancient Olympics. The Greeks used to glorify their athletes, conferring the highest honor on those who succeeded in demonstrating athletic expertise. For decades, athletic numbers running, jumping and throwing were the focus of activities in the Olympics. And in the period 664 BC people only did athletics, only after that was introduced another branch of sport.

The Romans fell in love with athletics since they conquered the Greeks. The Romans finally began to compete in the Olympics, until when King Theodosius banned it and abolished the Olympiad, in 392 A.D. based on considerations and reasons that the Olympics is an idol worship ceremony.

Eventually, the penchant for athleticism was rekindled from a bit and the race in this athletic sport began to be held sporadically on the Continent again in the middle ages. The popularity of athletic sports began to increase and spread widely since schools and universities in United Kingdom began to foster and enter into their respective educational environments.

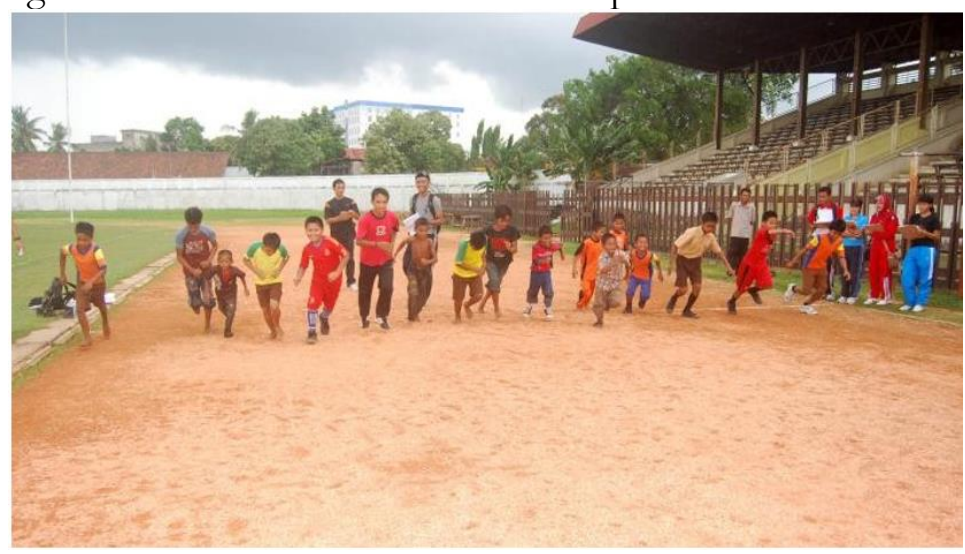

Source: Sukendro 2011

Figure 7. VO2 max test of primitive tribes

Of course the athletics have regained their superiority and virtue as they were once thanks to the revival of the Modern Olympiad movement starting in 1896 (in Athens). Until now the development of athletics has progressed well from the achievements of regulation and arbitration.

The latest regulations as outlined in IAAF sometimes interpretations of certain rules can lead to different opinions even among experienced referees. For this reason the need for race 


\section{Britain International of Linguistics, Arts and Education (BIoLAE) Journal \\ ISSN: 2685-4813 (Online), 2685-4805 (Print) \\ Vol. 1, No. 2, November 2019, Page: 253-262}

rules can be applied early on, especially for athletic specialties such as running numbers from 800 to 1500 meters at the age of 13-14 years. And this is found in primitive tribe. Likewise in providing the training programs if talent has been identified, it is necessary to provide forms of training in accordance with the principles of training such as the principle of overload principle.

This can all be done if primitive tribes does not experience any disorder or abnormality in the motion system, because there are basically two disorders of the motion apparatus in humans, namely: the muscles and bones. To achieve a healthy and fit level of life, we must have two religions, namely: spiritual religion and physical religion. Spiritual religion is the business of the scholars. Whereas physical religion is diet and exercise. As long as we breathe, we must exercise, so that the body functions optimally.

Humans in carrying out their lives are largely determined by the ongoing or moving processes in the body, such as blood circulation, heart rate, breathing, digestion, and other physiological processes. Furthermore, moving to do various activities or do physical work, for that all energy is needed, all of which we can find in athletics, especially middle-distance running numbers. Intermediate distance running is an athletic number that requires endurance, and in addition it is a test of ligaments, tendons, muscles, shins and legs, and ankles. Sir Roger Bannister, 1500 British runner who first time breaking in under 4 minutes stated, that today's runners must train heavier two or three times harder than athletes of his generation.

The strenuous exercise opens up greater opportunities for injury due to stress. Leg muscles are wrapped tightly by fascia (stringy screams) which protects the softer muscle fibers and guides the contractions. However, its function is important to limit the space for muscles to experience hypertrophy. The result is a pain called compartment syndrome, which is mostly felt on the front, but often also affects the inside of the calf muscles. The reason is the limited blood supply and needs to be treated by cutting the fascia bond. Dr. Almquist who treated American runners, Mary Decaer, at the age of 14, did not operate on athletes who were experiencing growth. There is also evidence to suggest that pain is due to small fractures in the shin or muscles attracted to the periosterum (the fibrous layer that covers the bones). Circumstances cause what is called Shinsplin.

Each injury that causes pain, gets worse if the activity takes place on a hard track or heat. Tenosynovitis on the Acholes tendon, or swelling of bursal sacs under the skin or bone, occurs due to excessive friction that requires rest and shoe replacement. With good shoes, the irritation can be removed.

The Guidance Talent Sports Guideline is explained about talent strategies and programs as direction and guidance in order to improve development performance in the field of sports through efforts to obtain quality athlete seeds, with the aim that talent scouting programs can be carried out in accordance with existing integrated planning and policies and obtain maximum results by using Sport Search The need for standard instruments to assess the progress of sports development is increasingly pressing to be met as the direction of national development policy goes from centralistic to decentralized.

The spirit of decentralization which came to be known as regional autonomy will in turn give greater authority to the regency/city regions. As stated in Law No. 22 of 1999, that local governments are given the authority to manage all sectors of community life, except in the fields of foreign policy, security, justice, fiscal, monetary, and religious. With the authority that is owned, the region can compete in a healthy manner in carrying out sports development. Regions can also formulate and take policies that are considered conducive to the development of sports 


\section{Britain International of Linguistics, Arts and Education (BIoLAE) Journal \\ ISSN: 2685-4813 (Online), 2685-4805 (Print) \\ Vol. 1, No. 2, November 2019, Page: 253-262}

in their area. Thus at certain moments such as sports day National, not only filled with activities that are ceremonial, but also the publication of the success of regional sports development throughout Indonesia.

Therefore, to measure the level of sports development in an area, namely the concept of "Sport Development Index" (SDI), with four dimensions, namely open space, human resources, participation, and fitness. The way to measure the level of physical fitness is by using the Multistage Fitness Test (MFT). This test is considered relevant for use in various ages, such as children, adolescents, and adults.

To get the level of physical fitness one of them requires talents that have special abilities that stand out among the various types of abilities a person has. This special ability is usually in the form of skills or a field of science, sound arts, sports, mathematics, language, economics, engineering, teacher training, social, religion, and so on. Someone generally has certain talents that consist of one or more special abilities that stand out from other fields. But there is also no talent at all, meaning that in all fields of science he is weak. There are also some people who have all-round talent, meaning that almost all fields of science and skills, he is capable and prominent. Such people are classified as special and able to live anywhere.

In accordance with the research that is being composed by researchers, it will be seen that one's giftedness is not just one branch of sport but multi-branch sport. As achieved by Jim Thorpe who won the Olympic Games in 1912 on decthlon and pentathlon numbers and so did Babe Didrikson.

At the age of 18 , he won a gold medal in numbers, shot put, baseball, long jump, 80 meters goal, high jump and javelin he did in 1932. On the other hand, intelligence and talent, is one aspect and personality and at the same time is a potential that is owned by someone. Therefore, the level of intelligence possessed by someone influences their behavior and personality. For example, someone who has a normal level of intelligence, or intelligent, will have a different type of personality, compared with classified as abnormal (debil, embesil, idiot) or classified as supernormal (genius).

Likewise, someone who has special talents, such as music, sound art, painting, or technical talent. Someone who has artistic talent, tends to become an artist. Someone who has technical talent, or numerical talent (numbers), he is likely to be an engineer or a mathematician. Similarly with someone who has talent or potential in sports, then he will become a sportsman.

The same was conveyed by Ricahard that Knowledge Skills, is also one aspect of personality, and influences personality. Therefore a person who has extensive knowledge, and high skills, as a result of the education and training process he goes through, then he tends to have personality traits that are far different, compared to people who have never received any education or training at all. In the context of sports, it turns out that some personality characteristics of athletes tend to have certain differences compared to those who are not sportsmen.

Field experience shows that to reach peak performance in a sport must begin at an early age through a systematic and continuous coaching process. In an effort to improve the achievements of the Golden Garuda Movement, is a strategic preparation step undertaken to anticipate the needs and demands of future sports coaching needs. Ragunan State Junior High School/Senior High School and the Center for Education and Sports Student Training is a place 
for the education and training of talented sports athletes, who carry out performance training and academic education.

\section{Conclusion}

Primitive tribe always to move to find a new life in order to continue their survival. They live in groups in one area. Their habitation is far into the forest which is difficult to reach by vehicles and must walk approximately $25 \mathrm{~km}$ from the nearest village or hamlet, this illustrates the endurance of their lungs very well.

The children are very agile in terms of catching snakes, especially snakes that often walk on water, by peeking and then gathered, then cut, boiled for food. Coordination and agility are very good, besides that they have strength and agility in terms of climbing which in itself will have good arm strength and leg grip.

Besides that they are proficient in hunting because hunting is the most important livelihood, they have the knowledge to succeed: the forest situation, natural signs, animal signs and how to catch them, because since childhood this generation has been trained to live deftly in the forest, of course has incredible speed and reaction and strength in getting hunted animals.

\section{References}

Ahmadi, A., and Munawar, S. (2005). Psikologi Perkembangan. Jakarta : PT. Rineka Cipta.

Asisten Diputi Pembibitan Olahraga Deputi Bidang IPTEK dan Olahraga Prestasi Kementrian Pemuda dan Olahraga Republik Indonesia. (2009). Sistem Pembinaan Olahraga.

Ateng, A. (2002). Keefektifan Model Pemasalan dan Kontribusinya Terhadap Usaha Pencapaian Prestasi Olahraga Besar Asia Tahun 2002. Paper. Retrieved from seminar ilmiah olahraga PON XII (Jakarta, PB PON XIII)

Arifin, M., et al. (1990). Perubahan Pola Kehidupan Masyarakat Akibat Pertumbuban Industri di Daerah Jambi. Depdikbud Provinsi Jambi.

Ackland, B., J and Elliot Bruce. C., (1994). Applied Anatomy and Biomechanics in Sports: Melborne. Blackwell Scientific Publications.

Baradja, B. (2005). Psikologi Perkembangan tahap-tahap dan aspek-aspeknya dari 0 tahun sampai akhil baliq. Studia Press. Jakarta-Timur.

Bompa, T., O. (1999). Periodization: Theory and Methodology Training. 4th Ed. USA. Human Kinetic. Bompa. T., O. (1990). Theory and Methodology of Training 2nd Ed. Debuque: Kendall / Hunt Publishing Company.

Colvin, G. (2008). Talent Is Overrated. United States of America.

Depdikbud. (1986). Sejarah Revolusi Keemerdekaan Daerah Jambi. Depdikbud Jambi.

Depdikbud. (1986). Ungkapan Tradisional Sebagai Sumber Informasi Kebudayaan Daerah Jambi. Depdikbud Jamb.

Depdikbud. (1990). Kamus Besar Bahasa Indonesia. Jakarta: Balai Pustaka.

Depdikbud. (1998). Dampak. Modernisasi Terhadap Hubungan Kekerabatan Pada Suku Bangsa Melayu Jambi. Jambi: Depdikbud Jambi.

Desmita. (2009). Psikologi Perkembangan. PT Remaja Rasdakarya. Bandung.

Dinas KSPM. (2009). Profil Komuditas Adat Terpencil (KAT) dan Program Pemberdayaan di Provinsi Jambi.

Direktorat jendral olahraga Departemen Pendidikan Nasional. (2000). Pedoman Mekanisme Koordinasi Pembinaan Olahraga, Kesegaran Jasmani dan Kelembagaan Olahraga

Direktorat Jendral Keolahragaan Petunjuk Pelaksanaan Teknis Penerimaan Siswa. 1999/2000. Eprint. Pengembangan Gerak Dasar-dasar lari. Uny.ac/484/I. PDF. 
Fachruddin, S. (2001). Pemberdayaan Komunitas Adat Terpencil di Provinsi Jambi (PermasalahanPemaparan dan Pelaksanaan). Jambi.

Fachruddin, S. (2002). Pemberdayaan Model Entry Point Komuditas Adat Terpencil (KAT) di Provinsi Jambi. Bagian Proyek Pemberdayaan Komuditas Adat Terpencil Jambi). Jambi.

Gufron, A. (2009). Asal Usul Suku Kubu (Online)

(http:/ /www.pangeranbekicotx.blogspot.com, Accessed on 23 March 2010)

Gunarsa, S. (2004). Psikologi Olahraga, Jakarta. Gunung Mulia.

Guyton. (1993). Buku Ajar Fisiologi Kedokteran. Buku Kedokteran EGC.

Harre, D. (1982). Principles of Sports Training, Berlin Sportverlag.

Harsono. (1988). Coaching dan Aspek-aspek Psikologis dalam Coaching. Depdikbud.

Ibrahim, R. (2001). pembinaan ketahanan di sepanjang hayat: pendekatan praktis melalui pendidikan jasmani).

Idrus, P. (2009). Statistic Deskriptif. Yogyakarta: Satria Insonia Press.

Irianto, K., and Kusn, W. (2004). Giz̨i dan Pola hidup Sehat. Bandung: CV. Yrama Widya.

Iskandar, Y. (2008). Test Bakat, Minat, Sikap dan Personaliti. Jakarta: Dharma Oraka Group.

Jim Brown. (2001). Sports talent, how to identify and develop outstanding athletes.

Kartasapoetra, M. (2002). Ilmu Giz̨i. Jakarta: PT. Asdi Mahasatya.

Kementrian Negara Pemuda dan Olahraga Republik Indonesia. Undang-Undang Republik Indonesia Nomor.3 Tahun 2005 Tentang Keolahragaan Nasional, 2005.

Keppres No: III/1999. Tentang Pembinaan Kesejahtraan Sosial Komuditas Adat Terpencil dan Kepmensos No: 06/PEGHUK/2002 Tentang Petunjuk Pelaksanaan KAT: 2002.

Kantor Menteri Negara Pamudan Dan Olahraga (Pedoman Pemanduan Bakat Olahraga): 1998

Koran :Jambi Ekspres, jambi 18 September 2010 Koran: Tribun jambi, Jambi 25 Agustus 2010

Lutan Rusli. Penanggulangan Cidera Olahraga pada Anak Sekolah Dasar. Jakarta. Depdiknas. 2009

Mastum Simanjuntak. Kamus (Irup Pelbetorat) Toba Alias Kubu-Indonesia. Jambi. 2009

Muthohir Thoho Cholik Olahraga dan Pembangunan meraih kembali kejayaan) . Jakarta. 2004

Partino, Idrus. Statistik Deskriptif. Safiria Insania Press.Yogyakarta. November. 2009

PASI. Peraturan Perlombaan Atletik. PB.PASI: Etika Parahyangan, 1996.

PB.PASI. Petunjuk Praktis Perwasitan Atletik. PB.PASI, 1998.

Pemerintah Provinsi Jambi Dinas Kebudayaan dan Pariwisata provinsi Jambi: Pameran Sekilas Kehidupan Orang Rimba Di DAS Batanghari. Musium Negeri Jambi 2010

Pererim, Hallam, Sport Management Course for Key Sport Aministration. Parthway for Junior Sport Talent Development, Cooperation Between the Government of Indonesia and Western Australia. 17-23 February 2008. Pert. Department of Sport and Recreation 2008.

Phaidon. Performance Nutrition. Jakarta: PT. Gramedia, 2008. Richard H. Cox Sport Psychology:Conceps and Aplication, 1985

Rusli Lutan. Penanggulangan Cidera Olahraga pada Anak Sekolah Dasar. Jakarta: Depdiknas, 2002.

Sanapiah, Faisal. Sosiologi Pendidikan. Surabaya: Usaha Nasional, 2003.

Satori, Djam'an, dan Aan Komariah. Metodologi Penelitian Kualitatif. Alfabeta. Bandung, 2009.

Shinya, H. The Miracle of Enzyme. Council Oak Books, Tulsa, Oklahoma. 2007.

Simanjuntak, M. (2008). Selayang Pandang Anak Lintang Bukit Barisan Suku Tebo Atau Kubu.

Pematang Siantar: Kolportase Pusat Gereja Kristen Protestan Indonesia.

Slamet, J., S. (1994).Kesebatan Lingkungan. Yogykarta: Gajahmada University Press.

Sugiyono. (2009). Metode Penelitian Kuantitatif Kualitatif dan R \& D. Bandung: Alfabeta.

Sugiyo. (2005). Statistika Untuk Penelitian. Bandung: Alfabeta. Sudjana. Metode Statistika. Bandung: Tarsito. 